\author{
Accepted manuscript of \\ Amanda Brandellero \& Susanne Jansen (2014) \\ Popular music as cultural heritage: scoping out the field of practice. \\ International Journal of Heritage Studies, 20(3), 224-240 \\ Online first February 2013: 10.1080/13527258.2013.779294 \\ Link to this article: http://dx.doi.org/10.1080/13527258.2013.779294
}

\title{
Popular music as cultural heritage: scoping out the field of practice
}

\author{
Amanda Brandellero ${ }^{\mathrm{a} *}$ and Susanne Janssen $\mathrm{b}$ \\ aDepartment of Sociology and Anthropology, University of Amsterdam, \\ Amsterdam, The Netherlands;

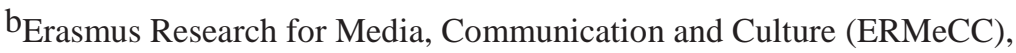 \\ Erasmus University Rotterdam, Rotterdam, The Netherlands
}

This paper sets out to deepen our understanding of the relationship between popular music and cultural heritage and to delineate the practices of popular music as cultural heritage. The paper illustrates how the term has been mobilized by a variety of actors, from the public to the private sector, to highlight the value of particular popular music manifestations and justify or encourage their preservation and diffusion for posterity. We focus on Austria, England, France and the Netherlands - countries with diverse popular music histories and with varying national and international reach. Popular music heritage is present in national and local public sector heritage institutions and practices in a number of ways. These range from the preservation and exhibition of the material culture of heritage in museums and archives, to a variety of 'bottom-up' initiatives, delineating a rich landscape of emblematic places, valued for their attachment to particular musicians or music scenes. The paper points to an underlying tension between the adoption and replication of conventional heritage practices to the preservation and remembrance of the popular music and its celebration as an expression of the dynamism of contemporary popular culture.

Keywords: popular music; cultural heritage practices; music tourism; museums and archives

*Corresponding author: a.brandellero@uva.nl 


\section{Introduction}

Theories and discussions about heritage have generally centred around two key questions: what is heritage, and whose is it? In a generic sense, the contention is that heritage can be anything, and anything can be heritage. Or in the words of Smith (2006, p. 11), there is 'no such thing as heritage', as it is not an innate quality, but rather it becomes through discursive practices and meaning and value construction. Heritage is both a source of identity and a receptor of value attributed to it by communities, institutions and people. It encompasses a sense of time, providing a sense of one's own past (Lowenthal 1985 , p. 44), while at the same time becoming a 'resource for the present' (Graham 2002, p. 1004). Insofar as understandings of heritage are necessarily embedded in time and space (Harvey 2001), heritage is in itself a manifestation of culture, better understood in its representational sense, that is to say, in the meaning given to it (Graham 2002, based on Hall 1997, p. 3).

In its practice, heritage raises important questions about the mediation of the past and its use in the present (Johnson 1999, p. 204). The lenition and operationalisation of heritage is an active choice of inclusion, a 'political act'. It involves the selection of elements which are deemed symbolic of the past, expressive of 'desired' rather than 'necessary' continuity and of their relationship to culture and society in general (Blake 2000, p. 68). Indeed, in its selectivity, heritage is 'as much about forgetting as remembering the past', where the reminisced disinherits the forsaken other (Graham 2002, p. 1004). Conventionally, heritage has been regarded as something apart from the 'popular', as exemplified in government support targeting primarily high arts (Bennett 2009). As Shuker (2001, 68, cited in Bennett 2009, p. 477) remarked, 'popular culture' is constructed in opposition to this, as commercial, inauthentic and so unworthy of government support. Others have noted the juxtaposition of an official, standardised national heritage to its vernacular counter-part, characterised by the unofficial, diverse expression of individuals and the local (Ashworth and Tunbridge 2004, p. 216). Thus, heritage translates into a hierarchy, ranging from an institutionalised consensus-version of history, or Authorised Heritage Discourse (hereafter AHD), to the multivocality of subaltern and dissenting heritage (see Smith 2006, Tunbridge and Ashworth 1996). Because of its nature, heritage is all but universal. It evolves in time with the values, tastes and identities of the people involved in its production (Graham et al. 2000).

Heritage has also been researched in terms of its dualities: of localism vs global ism, national vs vernacular and tourist vs resident (Ashworth and Tunbridge 2004). The dualities highlight how heritage discourses and the positionality of their agency, alongside the related materiality, play a key role 
in shaping and reproducing heritage meanings and practices. In other words, they contribute to naturalising 'certain ideas about the immutable and inherent nature of the value and meaning of heritage within practices of heritage conservation, preservation and management' (Smith 2006, p. 5). Confining heritage to the realm of experts, as well as drawing a distinction between heritage as a thing of the past and the present, contributes to drawing boundaries between heritage and the present day. In recent years, spurred by the growing status and recognition of intangible heritage, bottom-up approaches to heritage identification have emerged, legitimating the role of communities as bestowers of heritage status (van Zanten 2004).

Our paper reviews conceptualisations and practices of heritage in relation to popular music at the national and sub-national level, in four European countries: Austria, England, France and the Netherlands. By popular music, we mean the form of music that is based on commercial aesthetics, produced within the framework of a music industry and primarily mass distributed. We exclude folk and traditional music from our definition, as it is generally less reliant on an industry for its production, distribution and consumption. We explore the extent to which national and international popular music heritage conceptualisations and frameworks have caught up with the democratising practices of heritage at the local level. Firstly, we look at how heritage is conceptualised and operationalised in national and subnational policies. Secondly, we identify the use of the term heritage in the field of music, particularly popular music at the local level. Taking as an entry point for our exploration the official websites and tourist guides of a number of localities in each country, we explore how the term heritage is put to use in its association with music. Our findings highlight a latent tension between music as a vibrant, intangible expression of contemporary culture and its heritagisation which tends towards replicating a more conventional 'bricks and mortar', tangible approach. Moreover, the practices of popular music heritage denote the interplay between the global and the local, where the former provides an aesthetic frame of reference of remembered transnational stars and music styles; whereas the latter provides the nurturing environment for home-grown talent, as well as the context in which personal and collective sonic memories are shaped and fixed in time and place.

\section{From inheritance to heritages}

The concept of heritage finds its roots in the 'highly individualised notion of personal inheritance or bequest' (Johnson 1999, p. 190). In its practice though, heritage has been associated with more collective understandings of shared inheritance, tied in with the delineation of 'imagined communities', 
particularly related to notions of nationhood (Anderson 1991). In this quest for cohesion, heritage has historically come to embody the dominant powers, be they religious, social or ethnic, and by this virtue, reproduce their position (see Graham et al. 2000, Connerton 1989).

Nonetheless, nowadays unitary notions of heritage come into stark contrast with a culturally pluralist society, with multiple and fragmented identities. Official, expert-driven notions of heritage contrast with understandings of unselfconscious everyday heritage, but also with the use of heritage in commercial, economic realms. In as much as heritage is a process of remembrance, we witness a democratisation of memory, where the production of archives and the preservation of the aegis of history is no longer the exclusive remit of professionals (Nora 1989). While the democratisation and secularisation of heritage (as discussed by Lowenthal 1998) is not a novelty, it has nonetheless gained in scale and intensity in recent times, particularly spurred by technological advances which allow for digitisation of the past and storing of larger masses of it (Harvey 2001). Some go as far as to decry the rise of a 'memory industry' (Klein 2000). Yet, by virtue of the fact that every society has a 'relationship with its past', heritage can be seen as a human condition which defies attempts to pinpoint its historically situated advent (Harvey 2001).

Heritage as a bridge to the past has translated into an economic resource, and one that has been primarily used in tourism strategies, economic development and regeneration (Graham 2002). This use of heritage is inscribed in a wider trend towards the heritageisation of the Twentieth Century, in which the nostalgic gaze on the past and the development of the 'heritage industry' is linked to economic decline (Wright 1985, Hewison 1987). Tourism more generally offers an insight into the 'social construction of place and people, whether from the viewpoint of the visitors, the host communities, or the state' (Britton 1991, p.475). A number of 'tourist gazes' are identified, 'self-consciously organized by professionals', such as travel guide writers, tour operators, tourism offices and so forth (Urry 1992). Moreover, through tourism, heritage is used to endow places with a 'unique selling point' (Ashworth and Tunbridge 2004, p.211). Against the backdrop of globalization and the erosion of local difference, cultural heritage and its manifestations must be contextualised within the contemporary world's struggle and interplay between the indigenous and the imported (Hannerz 1996). Heritage has come to be mobilised as part of local and national strategies 'rediscovering the local' in the wake of economic and cultural globalisation, spurring policies engaging with social cultural identification and giving rise to an 
economy of heritage, where heritage becomes a marketable commodity and tool for local distinction and competitiveness (see Kong 1999).

The resulting commodification of heritage has drawn a number of critiques, pointing towards the ensuing sanitation and trivialisation of heritage, as it voids of authenticity (Sack 1992, Tunbridge and Ashworth 1996, Smith 2006). Moreover, the global and local dimension of heritage reveal underlying negotiations over mutually-exclusive uses of limited spatial resources: while places strive to project an externally-competitive image of distinctiveness (Simmie 2001, Graham 2002), they are also theatres of internal planning pressures, where diverse local denizens put forward their claim on space, imposing their identity (for instance, via the intermediary of unofficial monuments and visual representations) (Graham 2002).

In its discourse and practice, heritage is most often grounded in territoriality, tied to a key preoccupation with tracing its origins and authentic expression (see Butler 2006). The territoriality of heritage translated in practice in the conservation movement of natural heritage (Waterton 2005) and the emphasis on sites and monuments, which lingers in Western practices of heritage at the international and national levels. The memory which heritage expresses 'crystallises and secretes itself' in place (Nora 1989, p. 7). Heritage is asked to retrace the historical trajectory of a cultural group, through materiality and practice (Hobsbawm 1983). In so doing, heritage plays a crucial role in the construction of places, as it connects past experiences to present day localities (Moore and Pell 2010). In their discursive and self-referential nature, places and sites of heritage acquire value and meaning only in our interaction with them or with a given social and cultural context (Smith 2006). Through the boundedness and materiality of heritage, we are called to question the process by which heritage is legitimised and how its meaning is negotiated in time and place.

\section{Methodology}

The present paper offers an analysis of heritage definitions and policies at the national levels and explores the extent to which music partakes in both formal and informal understandings and practices of heritage. In conceptualising the heritage of popular music, we build upon an understanding of heritage as a reflection of a 'chain of popular memory' (Harvey 2001, Johnson 2005), where remembrance processes occur from an individual, informal level to a societal, institutionalised one. Moreover, in our understanding of the institutionalisation and practices of heritage, we draw on the concept of 'path dependence', which, broadly speaking refers to the influence of history on the 
present (Berman 1998). Present day heritage practice can be traced back to 'historical sequences in which contingent events set into motion institutional patterns or event chains that have deterministic properties' (Mahoney 2000, p. 507). We understand these deterministic properties as being encapsulated in striving for cohesive identity, which reproduces its own preservation through a variety of formal or informal institutional mechanisms that are in themselves self-referential. As identities are socially constructed, understanding heritage requires looking at a longer-term perspective and at the field of action of institutional actors. Mahoney's analysis of path dependence (2000, p. 517) encourages us to look at heritage not just from a perspective of power relations, but also of the utilitarian, functional role heritage fulfils. This perspective allows us to see the longer term trajectories, patterns and the role heritage fulfils and has fulfilled in time - as 'we learn to control it lest it controls us' (Lowenthal 1998, p. 226). Moreover, it helps understand current heritage practices in relation to the agents and processes of change (e.g. from the global conventions on heritage to the recognition of intangible heritage for instance).

More specifically, this exploratory research entailed mapping the conceptualisations of heritage by looking at the national cultural and heritage policies in four countries: Austria, France, the Netherlands and the UK. Our analysis drew on the key national texts and legislative documents, providing definitions and strategies in the field of heritage (ministerial responsibility, heritage codes and legislation). Secondly, we explored institutional approaches to popular music heritage, identifying a range of public and private actors in the field, engaged in the preservation and contemporary use of material and immaterial culture related to the popular music past. Thirdly, we studied the expression of popular music as cultural heritage at the local level, in designated localities. Our understanding of the local is twofold: on the one hand, it reflects the spatial boundaries which are constitutive of our localities (e.g. Amsterdam or The Hague's city limits); on the other, as described by Cohen (1991) in her work on Liverpool's rock music scene, it reflects the symbolic attachment of music making to the everyday lives of communities in place. We did this from the vantage point of the official city websites and official tourism websites of a number of $\operatorname{cities}^{1}$ in the four countries. Here we looked for references to popular music as a place-specific resource, and how it is mobilised as an asset in tourism and place promotion strategies. We review the different institutions and actors that 'do popular music heritage' in the four countries. By this, we mean the actors and institutions that are involved in processes of selection, preservation and use of the popular music past for present use, and for use by future generations. 
Rather than applying a priori restrictions on our field of research, we allow for our understanding of heritage to emerge from the practices of what is preserved, how and by whom, and how the process of giving value to the past for the benefit of present and future generations occurs.

\section{Popular music heritage: definitions and practices}

The terminology used in the four countries varies greatly, denoting the semantic evolution of the term (Vecco 2010). Heritage, cultural goods, cultural property, historical monuments and sites are used interchangeably (see Vecco 2010). At the governmental level, cultural heritage is defined via its practice and materiality, rather than by its underlying principles and meanings. Cultural heritage thus is museums, archaeology, libraries and buildings and sites of historical significance. In France, heritage or patrimoine is combined with architecture, while planning features prominently in the Dutch approach, where the conservation of physical heritage is tied to its sustainable and adaptive use for current needs. In recent years, we note a move towards greater rationalisation and streamlining of heritage policies resulting in clearer definitions, though in practice the term varies greatly in its implementation.

At the national level, music heritage and popular music heritage in particular remain relatively undefined. One exception is the 2009 study commissioned by the Dutch government defining musical heritage and exploring the feasibility of linking up all music archives and collections through a centralised search system (MCN and NMI 2010). The study provided a tentative definition of music heritage, enumerating the type of material culture ranging from classical to popular (though significantly biased towards the former), yet its recommendations were not pursued due to funding cuts in the cultural sector.

Irrespective of this definitional paucity, popular music heritage is present in national and local public sector heritage institutions and practices in a number of ways: (1) through the preservation and exhibition of the material culture of popular music in heritage institutions, such as museums and archives; (2) through their involvement in the active preservation, more recently through digitalisation specifically, of selected popular music material; (3) by the institutional recognition of the 'heritage heroes of yesteryear' (Harvey 2001, p. 337); (4) through a variety of 'bottom-up' private initiatives which in some cases evolve into public institutions; and (5) through the local marking, conservation and/or framing of emblematic places, valued for their attachment to particular musicians or music scenes (partly 
connected to the realm of local tourism strategies and practices). We address these here in turn.

\section{Preserving popular music's past through public heritage institutions}

Museums, archives and libraries play a key role in heritage practices in the selected countries. The former developed as repositories of national identity and cultural achievement (Bennett 1995); the latter two are broadly understood as a 'documentary by-product of human activity maintained for their long-term value' (International Council of Archives website, accessed 10 May 2012). In recent decades, concomitantly with the development of social history museums (Macdonald 1997), the increased cultural legitimacy of popular music (Schmutz et al. 2010) and the processes of democratisation of memory (Nora 1989), popular music has become the object and subject of official heritage institutions in the form of local museum exhibitions and dedicated archival collections.

The permanent collections of public museums on music tend to focus on 'serious', contemporary music and musical instruments, as is the case with the Haus der Muzik in Vienna and the Musée de la Musique in Paris, part of the wider Cité de la Musique complex, which includes a concert hall, a research centre and a conservatory. The former focuses its attention on more contemporary sounds in the context of the rise of technologies and modern soundscapes. The latter, as set out on its website as of 12 February 2013, vows to take its visitors on a musical world tour '[f]rom the Renaissance to today [...], and through the history of music. A guide presents the jewels of our collections: a Stradivarius violin, the Érard piano played by Franz Liszt, Django Reinhardt's guitar, and an extremely rare Thai piphat mon orchestra'. More variety is found in the temporary exhibitions, which focus on iconic figures of the popular music past, homegrown and from abroad. In particular, the conceptual under- pinning of these exhibitions fall under what in Leonard's (2010) typology of popular music exhibitions in museums would be 'canonical representations'. The authorising function of these heritage institutions is clearly revealed in the selectivity of their gaze and the accompanying legitimising discourses, which draw upon a combination of local and global aesthetic referents. The Musée de la Musique's 2012 exhibition on Dylan and 'the explosion of rock' precludes any debate by framing the artist as 'without a doubt, one of the key figures of music from the second half of the twentieth century', providing indirectly the rationale for the exhibition. Similarly, an earlier exhibition on Georges Brassens framed him as 'French icon' par excellence, citing him as the most influential French 
musician abroad.

There are nonetheless examples of permanent popular music collections in public museums, often with mixed fates. The 1994 shake-up of the Musée des Musiques Populaires in Montluçon, is particularly emblematic here. Under the impetus of the sociologist and curator Marc Touché, the museum's collection of bagpipes and lutes was extended to include 'musiques électroamplifiées' (literally, electronic and amplified music). Touché was instrumental in sparking a discussion on the country's sonic social history, bringing popular music in from the margins of institutionalised cultural legitimacy, while shaping museological practices in relation to collecting and displaying musical expressions and socialisation with a greater awareness of dynamics of identification and contestation (Touché 2007). In England, the short- lived National Centre for Popular Music in Sheffield, a 'showcase for the historical, cultural and social impact of pop', opened its doors in 1999, funded primarily by National Lottery funds (Ward 1999). The centre was criticised for its limited hands- on approach and lack of rock memorabilia, but also raised early concerns over the sustainability of its business case and audience base, causing it to go into administration in just over a year from its opening (Wilkinson 2000).

\section{Preservation of popular music culture}

In all countries, publicly financed institutions are engaging in the preservation of audio-visual recordings, part of a wider trend towards (and indeed delineated public funding streams for) digitisation. Organisations such as the British Library's Sound Archive Collection, the Dutch Centrale Discotheek Rotterdam and Beeld en Geluid (Central Record Library Rotterdam and the Image and Sound institute), the Austrian and French mediatheques (sound and video recording libraries) strive to collect all music produced and commercialised in their respective countries, relying on voluntary donations by artists or royalties collecting agencies, loans and purchases. Copyright issues weigh heavily on their activities. The material in these organisations is available for individual use and research. The British Library's Sound Archive website, for instance, states under its Collection Development Policy pages, accessed on 12 February 2013, that the rationale for present and future collection resides in 'the increasing importance and prevalence of multimedia and online resources in research and teaching, and the increase in student numbers' and the wider research community's priorities in oral history, identity and culture. The rationale for such collection is contemporaneously challenged and reinforced by the growing wealth of material available 
publicly via channels such as YouTube, as discussed in an interview with a representative of Beeld en Geluid. While these organisations provide a valuable way of cataloguing and rationalising the abundance of available material, the contemporary contingency reveals the ever-moving goal- posts of such organisations. Beyond their collection and preservation function, these institutions offer the opportunity for a more interactive engagement of audiences with the musical past. By example, the Dutch Fonos, previously part of Beeld en Geluid and now operating privately, and the Austrian Popular Music Archive, re-master or copy old and rare recordings in exchange for a fee. Moreover, most of these institutions have developed digital platforms allowing audiences to share reactions to or memories of archived material, part of a wider trend to 'crowdsource' the retrieval of music histories and past experiences (see Snoek et al. 2010, Cohen 2012). The analysis of the overwhelming public response to the yearly Dutch radio event Top 2000 identified a real need amongst audiences for public spaces to share experiences and memories, in order to create a collective common music heritage (van Dijck 2006).

\section{Remembering the icons of musical identity}

In its practice, heritage has generally taken the form of 'lists' of buildings, sites and more recently cultural practices. Moreover, heritage practice 'distils the past into icons of identity, bonding us with precursors and progenitors, with our own earlier selves, and with promised successors' (Lowenthal 1994, p. 43). In so doing, its 'selective portrayal' betrays 'a sense of nostalgia towards the heritage heroes of yesteryear' (Harvey 2001, p. 337). The list approach applies in the field, as is illustrated by the "national biographical dictionaries ${ }^{2}$ present in all countries, providing an overview of the personalities who shaped the history of their respective countries. The most emblematic popular musicians are remembered here, from the Dutch André Hazes to John Lennon, though the honour is bestowed posthumously.

Other forms of merit and recognition are bestowed onto people who have contributed to their particular field of activity in their lifetime. Such honours systems exist at various levels of government, from national to city level. In Austria, over the years, a number of schlager composers and singers have been rewarded with the Goldenes Ehrenzeichen (Gold medal). In 2011, Dutch classical musician Andre Rieu received such recognition on behalf of the Republic of Austria for his contribution to the spread of popularity of Viennese Waltz. In France, the honour of entering the Ordre des arts et des lettres (Order of the Arts and Letters) befalls upon artists over thirty who have 
distinguished themselves in the field of the arts and culture in France and abroad. Based on nominations by a committee or by the Minister of Culture, the selections have often sparked controversy, as with the recent rewarding of Shakira. In the UK, a number of popular musicians have entered the Most Excellent Order of the British Empire, an order of chivalry established in 1917 by King George V, including the members of the Beatles, Bee Gees, Status Quo and the Corrs. The uproar caused by the Beatles appointment as Members of the British Empire in 1965 was summed up by John Lennon as follows:

Lots of people who complained about us receiving the MBE received theirs for hero- ism in the war - for killing people... We received ours for entertaining other people. I'd say we deserve ours more. (Quoted in Roylance 2000, p. 183)

\section{Private initiatives for the preservation and promotion of popular music heritage}

Numerous private initiatives for the preservation and promotion of popular music as a cultural resource were originally set up in the late 1970s and 1980s by committed individuals with a passion for the art form and what Bennett would define 'a deeply invested DIY preservationist sensibility' (2009, p. 485). At the national level, a number of associations have evolved incrementally from their original focus on providing music industry support to embracing preservation, policy lobbying and research. In the Netherlands, the former Pop Instituut was set up in 1975 on initiative of musicians, to provide tax and social benefit advice and support fellow musicians with bureaucratic paperwork. Now part of the Muziek Centrum Nederlands (MCN, Music Centre Netherlands), the institute gradually evolved into a publiclyfunded archive and information centre on the country's popular music, as a result of a combination of active acquisitions and voluntary donations. In 2012, as the Centre faced imminent closure due to the government's axing of its financial support, the future of its archive and the ownership of the knowledge stored there was uncertain. The archive has now been transferred to the Special Collections of the University of Amsterdam, while Beeld en Geluid has taken over the running of the online Dutch Music Encyclopaedia which MCN used to maintain.

In France, the Centre d'Informations et Ressources pour les Musiques Actuelles, (Centre for Information and Resources on Contemporary Music) fulfils a similar role. Set up as an association in 1986, it provides support to different actors within the industry and is a strong voice in the preservation and dissemination of information and knowledge. In 2012, the French Centre 
National de la Musique (National Centre for Music) is set to incorporate and consolidate the work of existing music-related organisations, currently divided by genre. The Fédurok, a federation regrouping almost a hundred music performance and distribution venues in France, set up a project under the aegis of a 'Heritage Commission' (Commission Patrimoine), with a twofold goal: on the one hand, to support the digitisation of the members' archives; on the other, to chronicle the social history of popular music in France.

Individual collections and preservation attempts have also emerged in a number of countries, starting out as personal project of DIY preservationism (Bennett 2009) and growing into initiative with a wider heritage function. We find this ethos in the above-mentioned MCN (personal communication) and in a number of initiatives in all four countries. Rock Art, for example, started as a personal collection and archive, 'a treasure trove of Dutch popular music' (tagline to the museum), growing steadily over the years through acquisitions and donations, and becoming a museum in 2009. It hosts a permanent collection (the tip of the iceberg, compared to the vast, stored archive) and temporary exhibitions, celebrating national music movements and scenes or international stars (personal communication). While plans to turn the collection into a public national museum of popular music have stalled, partly due to financial issues, they raise challenging questions regarding the transition from a personal to a more institutionalised and official curatorial direction.

Similarly, the Hall de la Chanson in Paris is an association set up in 1990 by Serge Hureau, a 'crazy collector' (Hureau 1996) of material culture related to the French chanson. At its inception a personal mission, the Hall has evolved into the 'national centre for the chanson heritage', with the objectives 'to valorise the heritage of the chanson's oeuvre and its creators, often unjustly neglected or forgot- ten, to retrace its history and interpret its repertoire' (listed on Hall de la Chanson website, as of 18 July 2012, translated from French by the authors). Such rhetoric positions the hall as a site of contestation, legitimising the association's heritage practices in the face of a preservationist vacuum at an unspecified institutional level. The association now benefits from the support of the French Ministry of Culture and Education, and embodies a range of practices, from 'artistic, cultural and educational'. Opened as a charity in 2009, the British Music Experience embraces the mission to 'advance the education and appreciation of the art, history and science of music in Britain', as enunciated on the museum's website (accessed 12 February 2013). It also fulfils a preservation role by seeing to the acquisition, preservation and maintenance of artistic works, 
papers, interviews and artefacts related to this history. Apart from a permanent exhibition space, it hosts temporary exhibitions and provides facilities for research and study. Amongst the Experience's partners, we find some key players in the music industry, from Gibson Guitars to Sennheiser.

At the local level, a plethora of volunteer-driven physical and virtual archives and collections focused on local artists and music scenes reveal bottom-up heritage practices where preservation is experienced as a moral imperative, compelling individuals to perform a duty for a collective benefit. Echoing the findings of research into com- munity archives (Flinn et al. 2009), the rationale for setting up local music archives is based on the enthusiasm of an individual or group to document its history on its own terms, responding to a lack of visibility and representation within mainstream institutions (Harvey 2001). The Manchester District Music Archive, run by volunteers, provides an overview of the history of the city's music, searchable by bands, venue and artefact. Between 2002 and 2010, the archive was linked to URBIS, first a museum of the city life, then museum of popular culture, with a focus on popular music from the city. The museum has now been refurbished into a museum of foot- ball, and many of its former music centred exhibitions (for example, on the nightclub The Hacienda) are touring. While staying in England, the Birmingham Home of Metal is a museum set up with the support of Heritage National Lottery Funds and based on donations to help 'secure [the museum's] identity' and 'honour[ing] a truly global musical phenomenon'. The enthusiasm for the museum's rationale echoed in news reviews of its opening: 'Heavy Metal was born in the West Midlands and has developed a global following matched only in Hip-Hop. It's time to stop sneering and celebrate this proud cultural heritage...' (New Statesman, 30 July 2007).

\section{Local narratives/meanings and uses of the popular music past}

European national definitions of heritage have kept the pace with international developments and frameworks (UNESCO, ICOMOS). The practice of heritage has nonetheless been characterised by a devolutionary trend, as local and regional authorities and agencies are called upon to manage heritage. The management of heritage becomes enmeshed with spatial planning and cultural tourism. Here a diversity of actors, as public, private and spontaneous individual initiatives, contribute to shaping and preserving the aural memory of places, putting forward coherent and dissonant narratives.

In practical terms, heritage takes a multiplicity of roles and constitutes 
numerous resources for the city reflecting a market segmentation of heritage audiences with different consumption patterns and preferences (Graham 2002). The expression of unique localities translates into the promotion of identity through the conservation and fostering of localism, while the standardisation of practices recalls a 'catalogue heritage', mobilising 'broadly comparable instruments with broadly comparable goals' (Ashworth and Tunbridge, 2004, pp. 210-213).

Heritage is used to 'endow places' with a 'unique selling point', to differentiate places from others and to market and sell places to locals and outsiders (Ashworth and Tundbridge 2004, p. 211). In so doing, places are framed as narratives, highlighting the 'dynamic and contested nature of places as social contexts, constantly constructed by means of shared language and symbolic meanings' (Lichrou et al.2008). The narrative translates into 'not only written media, such as documents, books, and brochures, but also spoken, visual and non-verbal media' (Stokowski, 2002, p. 372). Together, these media contribute to developing the "hereness' neces- sary to convert a location into a destination' (Kirshenblatt-Gimblett 1998, p. 7). In the local official tourist websites, we see what the emerging narratives are in relation to popular music. Music is mobilised in a variety of ways and we find a number of patterns here.

The unifying narratives work by association of a locality and an emblematic genre or musician originating from there, or having a strong connection with the locality at a key point of their artistic blossoming, or indeed with a key era of the locality's sonic history. Cities that have shaped and influenced popular music history nationally and globally claim to hold the top spot in fictitious rankings, as witnessed in the promotion on their tourism websites (as of 12 February 2013). Liverpool, according to the VisitLiverpool site 'is officially the World Capital of Pop, and the Fab Four are, of course, its most famous offspring', while according to the online travel guide for Vienna, Wien.info, the city is the 'world's music capital', where music is 'literally in the air', citing the illustrious composers who have lived there and its claim to being the birthplace of operetta and the waltz. Cities also cite long legacies of musical creativity, renewed over time. According to VisitLondon, the city's 'rock credentials are hard to beat', as the tourist information site traces five decades of 'spandex-stretching rock heritage' (as of 18 July 2012). Alternatively, on DenHaag.nl, The Hague becomes 'Pop Stad', or Pop City, describing the fifty-year bond with pop, which has delivered some of the Netherlands' most successful music acts over the years, such as Shocking Blue, Golden Earring and Anouk (site accessed 12 February 
2013).

The definition of a locality's unique selling point can also be oppositional, drawing on comparisons to other places, as in the case of the promotion material found on the New Manchester Walks' website, as of 12 February 2013:

Forget Memphis and the Mersey, Manchester is Music City, a factory of superior song-making and stirring soundscapes courtesy of The Smiths, Joy Division, The Fall, Buzzcocks, John Cooper Clarke, Oasis, New Order, Happy Mondays and Elbow - all spinning around the legend of the Hacienda, the world's hippest nightclub, chicer than the Copacabana, sexier than Studio 54, cooler than the Cavern or Cream.

We note also some contestation, where places argue for a claim over the most important years of bands and genres. The VisitLondon site for instance, as of 18 July 2012, while acknowledging the Liverpudlian origin of the Beatles, takes credit for 'their most important years', epitomised by Abbey Rd studios and homonymous album's cover.

The language is one of births, roots, origins, which provide the strongest claims to ownership and authenticity of musical heritage in the localities. On VisitBirmingham, as of 18 July 2012, music was filed under 'Heritage and Culture', as the city takes pride in being the birthplace of famous artists and bands, such as Black Sabbath, UB40, Led Zeppelin, while claiming to be 'without a doubt the hub of UK Bhangra', contributing to the city's diverse musical 'pedigree'. Tracing back the roots of musical genres and musicians to places, we see the burgeoning of initiatives appropriating particular forms of musical heritage.

The sonic past also offers narratives for neighbourhoods, as with the 'typical Amsterdam' levenslied musicians and 'working class heroes' of the Jordaan neighbourhood, and Paris's Pigalle venues and streets, as sung by Dutronc and Gainsbourg. City locations and landmarks immortalised on album covers become sites of pilgrimage: thus, the VisitLondon tourist information site offers guidance to Battersea Power Station and Heddon Street, featuring, respectively, on the covers of Pink Floyd's and David Bowie's albums. The musical past is also mobilised to give legitimacy and status to present day music consumption practices. The U4 discotheque in Vienna is promoted on Wien.info as 'the living room of Falco and the Viennese scene' (site accessed 12 February 2013). Narratives also connect to mythical venues of the past, their buzzing history of music and dance, and present day embodiment memories of the Alcazar in Marseille, now a public library, brought to life to the tunes of Georges Brassens and Johnny Halliday, 
as recollected on the Tourisme à Marseille website; or the Roundhouse in North London, a suggested destination part of one of the music day out itineraries on the VisitLondon site, is still basking in the glory of its heyday, when Jimi Hendrix and the Doors, performed there amongst others (both sites accessed 18 July 2012).

The memory of the icons of yesteryear is also anchored in territories, through commemorative rituals and markings. These are expressions of bodily performative memory (Connerton 1989), in the form of sites of ritual performances and habits that are essential to the transmission of social memory. Places are ascribed heritage value by actors in the public and private spheres. English Heritage runs a Blue Plaque scheme, originally known as 'memorial tablets', celebrating the link between the built environment in Greater London and the distinguished people who inhabited it in the past. Based on nominations, primarily by the public, then reviewed by a committee, the plaques commemorate posthumously individuals who have distinguished themselves in their field, in places in the capital of symbolic importance to their lives or careers. To date, a select number of popular musicians have a plaque erected (see Roberts and Cohen, 2013, this volume). English Heritage offers guide-lines for communities wishing to set up their own plaque scheme, and many alternative schemes with a wider geographical spread and more lenient rules have emerged over the years. Sheffield for instance runs its own plaque scheme entitled 'Sheffield Legends', honouring the city's most famous denizens past and present, including Def Leppard and Joe Cocker. The plaques are exhibited on a 'hall of fame' outside the City Hall.

Statues constitute another marker of performative memory that populates the built environment. Stengs (2009) discusses in detail the history behind the commemorative statue of Amsterdam levenslied singer Andre Hazés in the city's neighbourhood where the artist made allegedly his debut as a young boy. At the unveiling of the statue, funded by fans, Hazes' wife gave the first copy of her biography to the city's Mayor, symbolically offering the memory of the artist to Amsterdam. A site of spontaneous pilgrimage, the tomb of Jim Morrison at the Père Lachaise cemetery in Paris, has now become institutionalised in an 'Espace Morrison' surrounded by barriers that guide and constrain the performativity of remembrance and fandom at the site (Margry 2008). This is a site of contestation insofar as the fans' motivations range from mystical to rock'n'roll (Margry 2008). Again in Paris, the exterior of Maison Gainsbourg, the former home of the controversial musician who died in 1991, dons graffiti and a shrine, regularly spruced up by visiting fans. The neighbours' attempts to control and counter the nuisance were in vain, as 
the presence of the address in national and foreign guidebooks alike puts it firmly on the city's musical heritage map. There are now plans for a museum celebrating the life of the artist in situ.

Moreover, places of secondary importance in their claims to a musical birthright are remembered as sites of unforgettable performances, the impact of which extended far beyond the present crowds. Thus, the Refectory at Leeds University, is noted on VisitLeeds.com as the site where a memorable recorded live concert by the Who in 1970 was made, which went on to become 'one of the most successful live albums ever made' (site accessed 12 February 2013). The Kurhaus in Scheveningen near The Hague, for instance, concluded its career as a performance venue with a concert by the Rolling Stones in 1964, which remains to this day, rather paradoxically, a 'legendary evening for Dutch popular music' (Zuijderduin 2011).

Generally, most cities' tourist guides state that it is an organic mix of local creativity and infrastructure that gives them a legitimate place on their country's musical map. However, others take pride in a more active, topdown strategy of nurturing local scenes, as is the case in Linz. Here, from the late 1970s onwards, 'the people in charge of [the city's] positioning considered it inauspicious to attempt to mount a competition with these traditional bulwarks of bourgeois high culture, opting instead, in the sense of a culture of no one left behind, for more easily accessible versions of art and culture that stressed the elements of contemporaneity and experiment' (as stated on the Linz Capital of Culture 2009 website, accessed 18 July 2012). The city became a 'mecca for fans of underground music', while since the city's Ars Electronica festival has showcased its strengths in digital arts and technologies, further promoted in the framework of the successful European Capital of Culture 2009 bid.

Tourist perspectives of the sonic history of places tend to collapse time and place. More precisely, time 'is obliterated by place as heritage mapping becomes a reference guide to spatialised storylines rather than to a series of localised yet inter- dependent histories' (Johnson 1999, p. 194). This is exemplified in the walking tours, where decades are collapsed into one unifying stroll across space.

\section{Conclusion}

The paper has illustrated how the term heritage has been mobilised in relation to popular music by a variety of actors, from the public to the private sector. The intertwining of discourses and practices of popular music heritage with broader cultural narratives gives rise to new understandings of popular 
culture's role in the shaping and trajectory of culture (Bennett 2008). This is particularly the case in England, while we note a stronger legacy of the higharts legacy weighting heavily on the cultural legitimacy of popular music.

While official definitions of popular music heritage may be missing, we note a variety of heritage practices of preservation, exhibition, education and remembrance. The growing attention to popular music fits within wider paradigmatic shifts in traditional heritage institutions, engaging with their potential as agents of inclusion and diversity. At the same time, popular music heritage practices display a path dependent approach to the preservation and remembrance, centred on material culture and consecration practices tending more towards historicising and objectifying the popular music past, than conveying its dynamic and experiential contribution to cultural and societal change. The heritagisation of popular music is in fact characterised by the adoption of conventional tangible heritage formats and practices, such as the marking of places and the preservation and display of material representing the culture of popular music. Manifestations of this can be found in the preservation, exhibition and digitisation of the material culture of popular music in heritage institutions, such as museums and archives; the consecration and recognition of popular musicians as key markers of cultural identity, be it through bottom-up or more institutionalised initiatives; and finally through the value attached to symbolic locations in the popular music history of places and their contribution to wider economic and cultural development strategies. The act of remembrance is embodied in emblematic people and places, and to a lesser extent, in the preservation and display of more concealed musical histories and heroes.

To be sure, bottom-up, often amateur or fan-initiated practices have come to fill an institutional void of preservation and remembrance, becoming more institutionalised and professional in the process. Popular music as heritage translates into a wide spectrum of practices, from the DIY and public-sector-driven initiatives for the protection of local and national musical identities to the commodification of the popular music past in the framework of place, marketing strategies and tourism initiatives. While the inclusion of popular music allows for a broadening of heritage to more contemporary cultural forms, particularly in the way sonic histories are framed in our localities' tourist websites, we acknowledge that acts of remembering primarily reproduce the hegemony of the music industry and mainstream acts. In this sense, the practices of local popular music heritagisation that we observe from this vantage point resonate more widely than within local communities, as they attempt to engage with and appeal to wider audiences. 
These initiatives show the diverse roles popular music plays in the construction of personal and collective memories and their attachment to places.

\section{Acknowledgements}

This research has been supported as part of the Popular Music Heritage, Cultural Memory and Cultural Identity (POPID) project by the HERA Joint Research Programme (www. heranet.info) which is co-funded by AHRC, AKA, DASTI, ETF, FNR, FWF, HAZU, IRCHSS, MHEST, NWO, RANNIS, RCN, VR and The European Community FP7 2007- 2013, under the Socio-economic Sciences and Humanities programme.

\section{Notes}

1. For a list of localities and tourist websites, see Appendix 1.

2. Oxford Dictionary of National Biographies; Biographisch Woordenboek van Nederland; Dictionnaire de la biographie francaise; Österreichisches Biographisches Lexikon (although this runs only up to 1950).

\section{Notes on contributors}

Amanda Brandellero is a postdoctoral researcher and lecturer at the Department of Sociology and Anthropology of the University of Amsterdam, The Netherlands. Her research interests lie in the social production and locus of culture and the cultural and spatial dynamics of globalisation. Recently, she has researched the popular music heritage of the Netherlands within the framework of the project POPID. She is currently involved in a large-scale comparative project on the globalisation of high art. Her dissertation The art of being different: exploring diversity in the cultural industries (2010) received the Boekman Dissertation Prize for the best thesis in the field of cultural policies published in the Netherlands in the period 2009-2012. She has also been awarded the European Cultural Policy Research Award 2007 for her work on migrant cultural entrepreneurship.

Susanne Janssen is a professor of Sociology of Media and Culture and the chair of the Department of Media and Communication at the Erasmus School of History, Culture and Communication at Erasmus University Rotterdam. She is the academic director of the Erasmus Research Centre for Media, Communication and Culture (ERMeCC). Her research and teaching activities lie in the fields of cultural sociology, media and communications research and the sociology of the arts and literature. Since September 2010, she serves as director of an international collaborative research project on Popular Music Heritage, POPID for which she has been awarded a major European research grant (HERA JRP grant). She has served as editor-in-chief (with Timothy J. Dowd) of Poetics. 


\section{References}

Anderson, B., 1991. Imagined communities. London: Verso.

Ashworth, G.J. and Tunbridge, J., 2004. Whose tourist-historic city? Localizing the global and globalizing the local. In: A.A. Lew, C.M. Hall, and A.M. Williams, eds. A companion to tourism. Malden, MA: Blackwell, 210-222.

Bennett, T., 1995. The birth of the museum: history, theory, politics. London:

Routledge.

Bennett, A., 2008. Towards a sociology of popular music. Journal of Sociology, 44 (4), 419-432.

Bennett, A., 2009. Heritage rock: rock music, representation and heritage discourse. Poetics, 37 (5-6), 474-489.

Berman, S., 1998. Path dependency and political action: re-examining responses to depression. Comparative Politics, 30 (4), 379-400.

Biographisch Woordenboek van Nederland, 2013. Biographisch Woordenboek van Nederland 1880-2000. Availabe from:

http://www.historici.nl/Onderzoek/Projecten/BWN [Accessed 12 February].

Blake, J., 2000. On defining cultural heritage. International and Comparative Law Quarterly, 49, 61-85.

Britton, S., 1991. Tourism, capital and place: towards a critical geography of tourism. Environment and Planning D, Society and Space, 9, 451-478.

Butler, B., 2006. Heritage and the present past. In: C. Tilley, W. Keane, S. Kuechler, M. Rowlands, and P. Spyer, eds. Handbook of material culture. London: Sage, 463-479.

Cohen, S., 1991. Rock culture in Liverpool: popular music in the making. Oxford: Claredon Press.

Cohen, S., 2012. Musical memory, heritage and local identity: remembering the popular music past in a European Capital of Culture. International Journal of Cultural Policy. DOI:10.1080/10286632.2012.676641

Connerton, P., 1989. How societies remember. Cambridge: Cambridge University Press.

Flinn, A., Stevens, M., and Shepherd, E., 2009. Whose memories, whose archives? Independent community archives, autonomy and the mainstream. Archival Science, 9 (1), 71-86.

Graham, B.J., 2002. Heritage as knowledge: capital or culture? Urban Studies, 39 (5-6), 1003-1017.

Graham, B.J., Ashworth, G.J., and Tunbridge, J.E., 2000. A geography of heritage: 
power, culture and economy. London: Arnold.

Hall, S., 1997. Introduction. In: S. Hall, ed. Representation: cultural representations and signifying practices. London: Sage/Open University, 1-12.

Hannerz, U., 1996. Cosmopolitans and locals in world culture. In: Ulf Hannerz, ed. Transnational connections: cultures, people, places. London: Routledge, 102-111.

Harvey, D.C., 2001. Heritage pasts and heritage presents: temporality, meaning and scope of heritage studies. International Journal of Heritage Studies, 7 (4), 319-338.

Hewison, R., 1987. The heritage industry: Britain in a climate of decline. London: Methuen.

Hobsbawm, E., 1983. Introduction: inventing traditions. In: E. Hobsbawm and T. Ranger, eds. The invention of tradition. Cambridge: Cambridge University Press, 1-14.

Hureau, S., 1996. Serge Hureau, le fou collectionnant. Le créateur de la future Folie chanson évoque cette sorte de musée interactif parisien. In Liberation, February 28. Available from: http://www.liberation.fr/culture/0101170914-serge-hureau-le-foucollec- tionnant-le-createur-de-la-future-folie-chanson-evoque-cette-sorte-de-museeinteractif-pari- sien [Accesed 18 July 2012].

Johnson, N.C., 1999. Framing the past: time, space and the politics of heritage tourism in Ireland. Political Geography, 18, 187-207.

Johnson, N.C., 2005. Memory and heritage. In: P. Cloke, P. Crang, and M. Goodwin, eds. Introducing human geographies. 2nd ed. London: Hodder Arnold, 314-325.

Kirshenblatt-Gimblett, B., 1998. Destination culture: tourism, museums and heritage. Berkeley, CA: University of California Press.

Klein, K.L., 2000. On the emergence of memory in historical discourse. Representations, 69, 127-150.

Kong, L., 1999. The invention of heritage: popular music in Singapore. Asian Studies Review, 23 (1), 1-25

Leonard, M., 2010. Exhibiting popular music: museum, audiences, inclusion and social history. Journal of New Music Research, 39 (2), 171-181.

Lichrou, M., O’Malley, L., and Patterson, M., 2008. Place-product or place narrative(s)? Perspectives in the marketing of tourism destinations. Journal of Strategic Marketing, 16(1), 27-39.

Lowenthal, D., 1985. The past is a foreign country. Cambridge: Cambridge University Press.

Lowenthal, D., 1994. Identity, heritage and history. In: R. Gillis, ed. Commemorations: the politics of national identity. New Jersey, NJ: Princeton University Press, 41-57.

Lowenthal, D., 1998. The heritage crusade and the spoils of history. Cambridge:

Cambridge University Press. 
Macdonald, S., 1997. A people's story? Heritage, identity and authenticity. In: C.

Roject and J. Urry, eds. Touring cultures: transformations of travel and theory. London: Routledge, 155-176.

Mahoney, J., 2000. Path dependence in historical sociology. Theory and Society, 29 (4), 507-548.

Margry, P.J., 2008. The pilgrimage to Jim Morrison's grave at Pere Lachaise Cemetery: the social construction of sacred space. In: P.J. Margry, ed. Shrines and pilgrimage in the modern wold. New itineraries into the sacred. Amsterdam: Amsterdam University Press, 143-171.

Moore, S. and Pell, S., 2010. Autonomous archives. International Journal of Heritage Studies, 16 (4-5), 255-268.

Muziek Centrum Nederlands (MCN) and Nederlands Muziek Instituut [Dutch Music Institute] (NMI)., 2010. Muzikaal Erfgoed in Nederlands. Den Haag: Policy report.

Nora, P., 1989. Between memory and history: les lieux de memoire [Sites of memory]. Representations, 26 (Spring), 7-24.

Roberts, L. and Cohen, S. 2013. Unauthorising popular music heritage: outline of a critical framework. International Journal of Heritage Studies. DOI:

10.1080/13527258.2012.750619.

Roylance, B., 2000. The beatles anthology. London: Chronicle Books.

Sack, R.D., 1992. Place, modernity and the consumer's world. Baltimore, MD: Johns Hopkins University Press.

Schmutz, V., et al., 2010. Change and continuity in newspaper coverage of popular music since 1955: evidence from the USA, France, Germany and the Netherlands. Popular Music and Society, 33, 505-515.

Shuker, R., 2001. Understanding popular music. London: Routledge.

Simmie, J., 2001. Innovative cities. London: Spon.

Smith, L., 2006. Uses of heritage. London: Taylor \& Francis.

Snoek, C.G.M., et al., 2010. Crowdsourcing rock n' roll multimedia retrieval. Proceedings of the international conference on Multimedia, 10, 1535-1538.

Stengs, I., 2009. Death and disposal of the people's singer: the body and bodily practices in commemorative ritual. Mortality, 14 (2), 102-118.

Stokowski, P.A., 2002. Languages of place and discourses of power: constructing new senses of place. Journal of Leisure Research, 34 (4), 368-382.

Touché, M., 2007. Muséographier les 'musiques électro-amplifiées’. Pour une sociohistoiredu sonore [Museography and 'electro-amplified music': for a social history of sound]. La Découverte, Réseaux, 2 (141), 97-141. 
Tunbridge, J. and Ashworth, G.J., 1996. Dissonant heritage: the management of the past as a resource in conflict. Chichester: Wiley.

Urry, J., 1992. The tourist gaze 'revisited'. Americal Behavioural Scientist, 36, 172186.

van Dijck, J., 2006. Record and hold: popular music between personal and collective memory. Critical Studies in Media Communication, 23 (5), 357-374.

Vecco, M., 2010. A definition of cultural heritage: from the tangible to the intangible. Journal of Cultural Heritage, 11 (3), 321-324.

Ward, D. 1999. Bankrupcy threatens pop music centre. The Guardian, 19 October.Available from: http://www.guardian.co.uk/uk/1999/oct/19/davidward

Waterton, E., 2005. Whose sense of place? Reconciling archeological perspectives with community values: cultural landscapes in England.. International Journal of Heritage Studies, 11 (4), 309-325.

Wilkinson, M., 2000. Debts force $£ 15$ million pop music heritage centre into insolvency. The Independent, 19 October. Available from: http://www.independent.co.uk/arts-entertainment/ music/news/debts-force-pound15mpop-music-heritage-centre-into-insolvency-743875.html [Accessed 12 February 2013].

Wright, P., 1985. On living in an old country. London: Verso.

Zanten van, W., 2004. Constructing new terminology for intangible heritage. Museum International, 56 (1), 36-44.

Zuijderduin, R., 2011. Rolling stones in her kurhaus. Omroep NL, 24 September. Available from: http://www.publiekeomroep.nl/artikelen/rolling-stones-in-het-kurhaus [Accessed 18 July 2012]. 
Appendix 1. List of localities

\begin{tabular}{|c|c|}
\hline \multicolumn{2}{|c|}{ Main tourist information site } \\
\hline Austria & \\
\hline Carinthia & http://www.kaernten.at/ \\
\hline Graz & http://www.graztourismus.at/cms/ziel/2865539/EN/ \\
\hline Linz & $\begin{array}{l}\text { http://www.linz.at/english/tourism/ Linz Capital of Culture } \\
2009\end{array}$ \\
\hline & website: http://www.linz09.at/en/ueber_linz.html \\
\hline Tyrol & http://www.tyrol.com/ \\
\hline Vienna & http://www.wien.info/enhttp://www.aboutvienna.org/ \\
\hline \multicolumn{2}{|l|}{ France } \\
\hline Lyon & http://www.lyon-france.com/ \\
\hline Marseilles & http://www.marseille-tourisme.com/ \\
\hline Nantes & http://www.nantes-tourisme.com/ \\
\hline Paris & http://www.parisinfo.com/ \\
\hline \multicolumn{2}{|l|}{ The Netherlands } \\
\hline Achterhoek/ Liemers & $\begin{array}{l}\text { http://www.achterhoek.nl/ Erfgoed centrum Achterhoek en } \\
\text { Liemers: http://www.ecal.nu/ }\end{array}$ \\
\hline Amsterdam & $\begin{array}{l}\text { I Amsterdam: } \\
\text { http://www.iamsterdam.com/en/visiting/touristinformation } \\
\text { Visit Holland: } \\
\text { http://www.holland.com/global/tourism/Cities-in-Holland/ } \\
\text { Amsterdam/Cities-in-Holland/Amsterdam/Culture-in- } \\
\text { Amsterdam-1.htm }\end{array}$ \\
\hline The Hague & $\begin{array}{l}\text { Site of the municipality of The Hague: } \\
\text { http://www.denhaag.nl/home/ bezoekers.htm }\end{array}$ \\
\hline Limburg & http://www.limburg.nl/Beleid/Toerisme_en_recreatie \\
\hline Rotterdam & http://www.rotterdam.info/bezoekers/ \\
\hline \multicolumn{2}{|l|}{ England } \\
\hline Birmingham & Visitbirmingham.com http://www.visitbirmingham.com \\
\hline London & Visitlondon.com: http://www.visitlondon.com \\
\hline Leeds & Visitleeds.com: http://www.visitleeds.co.uk/ \\
\hline Liverpool & Visitliverpool.com: http://visitliverpool.com \\
\hline Manchester & Visitmanchester.com: http://www.visitmanchester.com \\
\hline Sheffield & $\begin{array}{l}\text { Sheffield tourism information site: } \\
\text { https://www.sheffield.gov.uk/out-about/tourist-information }\end{array}$ \\
\hline
\end{tabular}

